\title{
THE RELATIONSHIP OF FORMAL EDUCATION WITH MEN'S ATTITUDES TOWARDS SEXUAL BEHAVIOR IN INDONESIA 2017
}

\author{
Seri Aryati', Ratri Purnama Dewi² \\ 'Department of Environmental Geography, Faculty of Geography, Universitas Gadjah Mada \\ Yogyakarta 55281, Indonesia \\ ${ }^{2}$ Laboratory of Population dan Economic Resources, Faculty of Geography, Universitas Gadjah Mada \\ Yogyakarta 55281, Indonesia \\ Email corresponding: seri.aryati@ugm.ac.id
}

\begin{tabular}{|c|c|c|}
\hline Submitted: & Accepted: & Published: \\
$28-11-2020$ & $04-12-2020$ & $31-01-2021$ \\
\hline
\end{tabular}

\begin{abstract}
The phenomenon of dating in adolescents is considered common nowadays. The data shows that $84 \%$ of male adolescents in Indonesia claim to have been dating, 4\% higher than female adolescents in 2017. Dating has a big risk, which leads to premarital sexual behavior. The attitude of men towards premarital sexual behavior in Indonesia varies widely, from agreeing to disagreeing. This study aims to describe the relationship between the level of formal education and attitudes of male adolescents towards premarital sexual behavior in Indonesia in 2017. Kendall's Tau correlation test was used to determine whether there was a relationship between the two variables tested, namely the level of education and attitudes towards premarital sexual behavior. The data used is secondary data from the 2017 Indonesian Demographic and Health Survey (IDHS). The sample in this study amounted to 12.987 scattered throughout Indonesia. Quantitative descriptive analysis and spatial analysis were used to describe the distribution of correlation results in each province. Through this research, it can be seen that nationally there is a significant and positive relationship between the level of formal education and the attitudes of male adolescents towards premarital sexual behavior in Indonesia in 2017. However, when viewed from the distribution in each province, the correlation results vary.
\end{abstract}

Key words: relationship, formal education, premarital sex, male adolescents

\section{Introduction}

Dating is a phenomenon that is already considered normal by society (Azinar, Zahroh, $\&$ Harbandinah, 2011). Data shows that $80 \%$ of women and $84 \%$ of men in Indonesia are already dating (BKKBN, BPS, \& Ministry of Health, 2018). In fact, many studies have revealed that dating causes losses, such as violence by partners (Khaninah \& Widjanarko, 2016; Mudjijanti, 2010), mental disorders in one of the perpetrators of dating (Ratnawati \& Astari, 2019), premarital sex behavior (Setiawan \& Nurhidayah, 2008; Oktriyanto \& Alfiasari, 2019), and so on.

The negative impact of dating will be more pronounced when there are premarital sexual relations (intercourse). The follow-up effects of this behavior are many, ranging from unwanted pregnancy (KTD), abortion, and so on (Azinar et al., 2011). The 2017 Indonesian Demographic and Health Survey (IDHS) data shows that male adolescents are more permissive of premarital sexual behavior than women. This is influenced by biological factors, in which men's sexual drive is higher than women's (Wulan \& Muslihudin, 2003). In social construction, men are still considered as superior beings who are free to do anything, including premarital sexual behavior (Suwarni \& Arfan, 2015). However, previous studies have also revealed that there are other factors that can influence a person's attitude towards premarital sexual behavior. Rosdarni, Djaswadi, \& Sumarni (2015) show that there are several personal factors that influence premarital sexual behavior, namely knowledge of sexual health, attitudes towards sexuality, self-esteem, and self-efficacy. Exposure to television and internet viewing (about pornography) also has a significant relationship with premarital sexual behavior (Suwarsi, 2016). Meanwhile, Istiqomah \& Notobroto (2016) explained that 
premarital sexual behavior is influenced by knowledge and self-control.

The level of knowledge is in fact closely related to premarital sexual behavior. Meanwhile, the younger generation in Indonesia has different levels of knowledge, depending on the conditions in their respective provinces. Coupled with the lack of education about adolescent sexual behavior in formal education in Indonesia. This study aims to describe the relationship between the level of formal education and attitudes of male adolescents towards premarital sexual behavior in Indonesia in 2017. This study is based on the fact that male adolescents tend to agree with premarital sexual behavior. Although the percentage is small at the national level, the spread of perceptions of the fairness of premarital sexual behavior among adolescents will become easier with the rapid development of technology. This makes this topic important to study because it can be used as a reference in the preparation of delinquency prevention efforts related to premarital sexual behavior. In addition, studies at the national level that emphasize distribution in each province allow decision making in each province. This will make the efforts made by all stakeholders more focused on their respective areas.

\section{Methods}

This research is a type of quantitative research, which uses numbers as an analysis tool (Yunus, 2010). The data used is in the form of secondary data, namely the results of the 2017 Indonesian Demographic and Health Survey (IDHS). The IDHS data was chosen because of the complete information presented, both from a social and demographic perspective as well as the health of the Indonesian population. In addition, the IDHS data also provide special information on adolescents so that it can be used as material for a comprehensive study of the phenomenon of youth. The most recent IDHS data is the 2017 IDHS data. Previously, the IDHS has been implemented in Indonesia seven times starting from 1987, continued in 1991, 1994, 1997, 2002-2003, 2007, and 2012 (BKKBN et al., 2018). The IDHS data itself is obtained through the results of a survey conducted by the Central Statistics Agency (BPS), in collaboration with the National Population and Family Planning Agency (BKKBN) and the Ministry of Health (Kemenkes). The IDHS is also part of the international Demographic and Health Surveys (DHS) Program. The United States Agency for International Development (USAID) provides funding assistance and technical assistance.

The study of adolescent attitudes towards premarital sexual behavior and its relationship with the level of formal education was carried out using one of the components of the IDHS data, namely Adolescent Reproductive Health (KRR). The sample used is a sample of male adolescents in all provinces in Indonesia. There were 12,987 samples which were then processed using Kendall's Tau correlation test. The choice of Kendall's Tau correlation test is based on the type of data on the variables used, namely nominal and ordinal data. There are two variables in this study, namely attitudes towards premarital sexual behavior and education level. The attitude variable towards premarital sexual behavior was obtained from the answer to the question "Do you agree if a man has sexual intercourse before marriage?". These questions produce answers with nominal data types which consist of three categories, namely: 1 = agree; 2 = disagree, and $3=$ it depends. The education level variable is obtained from the answer to the question "What is the highest level of education you have / are currently attending: elementary school, junior high school, high school, academy, or university?". These questions produce answers with ordinal data types which consist of five levels, namely: $1=S D / M I$ equivalent; 2 = SMP / MTs / equivalent; $3=$ SMA / SMK / MA / equivalent; 4 = Academy / DI / DII / DIII; and $5=$ Diploma IV / University.

The results of the correlation test were then analyzed descriptively quantitatively. The interpretation made of the correlation coefficient value is based on the explanation of Cohen (1992) in Marshall \& Boggis (2016) in Table 1, which is as follows.

Table 1. Types of Relationships in the Correlation Test Based on the Correlation Coefficient Value

\begin{tabular}{cc}
\hline Correlation Coefficient Value & Correlation \\
\hline-0.3 to +0.3 & Weak \\
-0.9 to -0.3 and 0.3 to 0.5 & Medium \\
-1.0 to -0.9 and 0.9 to 0.9 & Strong \\
\hline
\end{tabular}


Spatial analysis was also carried out in this study, namely by looking at the distribution of the relationship between male adolescent attitudes towards premarital sexual behavior and the level of formal education in all provinces in Indonesia. The distribution is presented in the form of a map to facilitate understanding of the research results.

\section{Results and Discussions}

The effect of formal education on premarital sexual behavior has not been widely studied. Research on the relationship between education and premarital sexual behavior is more dominated by sexual education or reproductive health education. In fact, the existing education system in Indonesia is dominated by formal education, such as elementary, junior high, high school, and university. Through this research, several results have been obtained that can provide an overview of the relationship between formal education and the attitudes of male adolescents towards premarital sexual behavior.

The results of the correlation test in this study indicate that there is a significant relationship between the level of formal education and attitudes of young men towards premarital sexual behavior in Indonesia in 2017. The relationship between the two is a positive relationship. This means that the higher the level of education, the higher the level of male rejection of premarital sexual behavior. Another meaning is that the level of permissiveness of male adolescents towards premarital sexual behavior is getting lower along with the high level of formal education.

However, the relationship between the two can be said to be weak because the resulting correlation coefficient is only 0.027 . This means that formal education is not a variable that is closely related to the permissiveness of male adolescents to premarital sexual behavior. When viewed at the provincial level, the value of the correlation coefficient varies considerably, as well as the significance value. In fact, only eight provinces are significant (Figure 1). The provinces are DKI Jakarta, West Java, Central Java, Yogyakarta Special Region, Bali, North Sulawesi, Central Sulawesi, and Southeast Sulawesi.

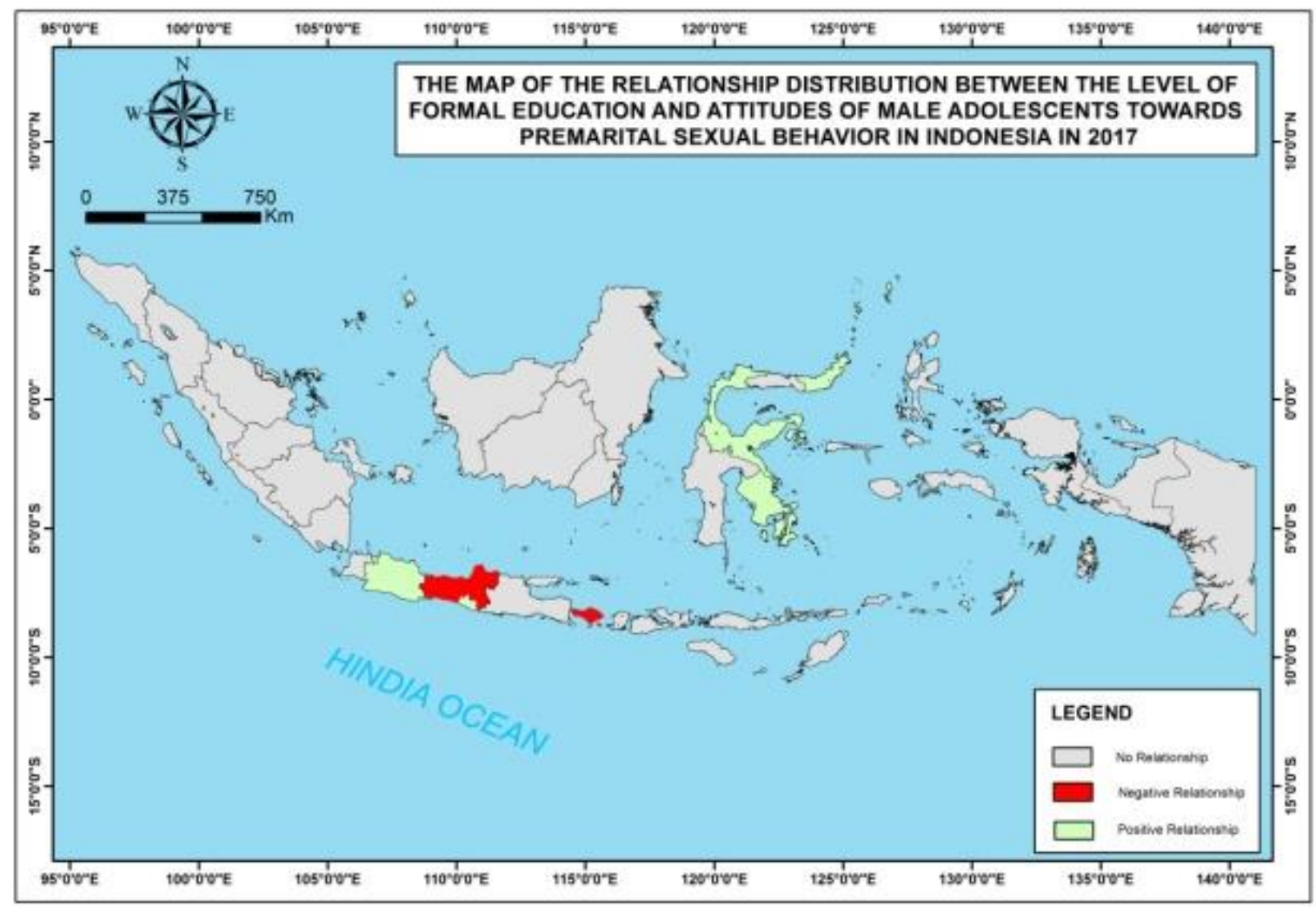

Figure 1. Map of the Distribution of the Relationship between the Attitudes of Young Men to Premarital Sexual Behavior and the Level of Formal Education in Indonesia in 2017 (Source: Research Results, 2020) 
The spatial data in Figure 1 shows that in fact, from the eight significant provinces, the direction of the relationship varies. Central Java and Bali provinces have negative correlation coefficient values, while the other six provinces have positive correlation coefficient values. This means that the attitude of male adolescents towards premarital sexual behavior and the level of formal education in Central Java and Bali has a negative relationship. The higher the level of formal education, the lower the level of rejection of premarital sexual relations among male adolescents. This indicates that young men with high education tend to be permissive towards premarital sexual behavior. As for the other six provinces with a positive relationship, it indicates that the higher the level of education makes male adolescents increasingly reject premarital sexual relations. To see the distribution of significance values and correlation values, it can be seen in Table 2 .

Table 2. Distribution of Kendall's Tau Correlation Test Results between Levels of Formal Education and Attitudes of Young Men to Premarital Sexual Behavior by Significant Provinces in 2017

\begin{tabular}{clrr}
\hline Number & \multicolumn{1}{c}{ Province } & Significant Value & Correlation Coefficient \\
\hline 1 & DKI Jakarta & 0,019 & $0,099^{*}$ \\
2 & West Java & 0,000 & $0,094 * *$ \\
3 & Central Java & 0,044 & $-0,065^{*}$ \\
4 & Yogyakarta Special Region & 0,026 & $0,154^{*}$ \\
5 & Bali & 0,003 & $-0,197 * *$ \\
6 & North Sulawesi & 0,010 & $0,205 * *$ \\
7 & Central Sulawesi & 0,002 & $0,156^{* *}$ \\
8 & Southeast Sulawesi & 0,026 & $0,101 *$ \\
\hline
\end{tabular}

**. Significant correlation at the 0.01 level (2-tailed)

*. Significant correlation at the 0.05 level (2tailed)

Source: Research Results, 2020

Table 3 shows that the value of the correlation coefficient in the significant provinces is at a weak level, which is between 0.3 to +0.3 . In line with the correlation results at the national level, it shows that the level of formal education is not really related to the attitudes of young men towards premarital sexual behavior. This is also supported by 26 other insignificant provinces. However, the average correlation direction in the insignificant provinces is positive. This means that there is a tendency to decrease the permissiveness of male adolescents towards premarital sexual behavior when the level of education is higher.

Variations in yields between provinces can be caused by various social and economic conditions of the community. As stated by Wellings et al. (2006) stated that different patterns of sexual behavior between regions are caused by variations in social and economic characteristics of the community. Developed countries in this regard are classified as high risk. This means that in areas where the economy tends to be developed, the pattern of sexual behavior is increasingly free. Religious and cultural factors also influence this (Pringle et al., 2017). As is well known, Indonesia has a variety of customs, cultures, and religions, so that the factor of formal education alone is not sufficient to influence the mindset of the younger generation towards premarital sexual behavior. Especially in male adolescents, who tend to be identified with humans who are free to do anything because they are men, not women (Suwarni \& Arfan, 2015).

The provinces of Bali and Central Java have an inversely proportional correlation with the other six provinces. Rahyani, Utarini, Wilopo, \& Hakimi (2012) explained that premarital sexual relations have spread very quickly to adolescents in Bali. Premarital sexual relations are also considered normal by the local population as long as they do not lead to pregnancy outside of marriage (Duarsa, 2005 in Rahyani et al., 2012). This new value that is accepted by society causes young men to be freer to have premarital sexual intercourse because they do not have a high risk after the relationship. A very high risk will be experienced by teenage girls because it can cause KTD (Unwanted Pregnancy). As for Central Java, research conducted by Azinar et al. (2011) show that the majority of adolescents who have premarital sexual relations in the capital city of Central Java, namely Semarang, are high school teenagers and university students. Apart from being the provincial capital, Semarang is also one of the largest cities in Indonesia with the third largest population. Coupled with the number of universities, with 
students who are teenagers, it makes cases of premarital sexual relations increasing. Most of these students have a free relationship so that premarital sexual relations cannot be avoided. Apart from social factors (the influence of close friends), premarital sexual relations in adolescents are also influenced by low religiosity.

\section{Conclusion}

The results of research on the relationship between the level of formal education and attitudes of male adolescents towards premarital sexual behavior in Indonesia show a weak positive correlation in 2017. Formal education alone is not sufficient to influence male adolescent rejection of premarital sexual behavior because other factors dominate., such as religiosity and association or peer influence. Nationally, Indonesia needs to strive to provide the best curriculum for formal education related to adolescent sexual education. In line with the research by Pinandari, Wilopo, \& Ismail (2015), that adolescents with formal education in which comprehensive reproductive health materials will reduce the number of adolescent premarital sexual relations. In addition, understandings of religious teachings must also be promoted so that the level of youth religiosity increases in all provinces in Indonesia. As for regionally, namely at the provincial level, efforts to reduce the high permissiveness of male adolescents to premarital sexual behavior must be intensified in the Provinces of Bali and Central Java, namely by improving the comprehensive reproductive health teaching system in formal education. Another alternative is also needed because in fact formal education is not sufficient to change the attitudes of male adolescents towards premarital sexual behavior in the province. Meanwhile, in the Provinces of DKI Jakarta, West Java, Yogyakarta Special Region, North Sulawesi, Central Sulawesi, and Southeast Sulawesi, it is hoped that the government can continue to improve the quality of formal education, especially regarding the dissemination of information on adolescent sexual health.

\section{References}

Azinar, M., Zahroh, S., \& Harbandinah, P. (2011). Perilaku Seksual Pranikah Berisiko pada Mahasiswa yang Menyebabkan Kehamilan Tidak Diinginkan (KTD). Jurnal Promosi Kesehatan Indonesia, 6(1), 9-18.
BKKBN, BPS, \& Kemenkes. (2018). Survei Demografi dan Kesehatan Indonesia 2017 Buku Remaja. BKKBN, Jakarta.

Istiqomah, N. \& Notobroto, H.B. (2016). Pengaruh Pengetahuan, Kontrol Diri terhadap Perilaku Seksual Pranikah di Kalangan Remaja SMK di Surabaya. Jurnal Biometrika dan Kependudukan 5(2), 125134.

Khaninah, A. N. \& Widjanarko, M. (2016). Perilaku Agresif yang Dialami Korban Kekerasan dalam Pacaran. Jurnal Psikologi Undip 15(2), 151-160.

Marshall, E., \& Boggis, E. (2016). The Statistics Tutor's Quick Guide to Commonly Used Statistical Tests. University of Sheffield.

Mudjijanti, F. (2010). Masa Pacaran Dini (Early Dating) dan Dampaknya. Widya Warta (1), 47-57.

Oktriyanto \& Alfiasari. (2019). Dating and Premarital Sexual Inisiation on Adolescence in Indonesia. KEMAS 15(1), 98-108.

Pinandari, A.W., Wilopo, S.A., \& Ismail, D. (2015). Pendidikan Kesehatan Reproduksi Formal dan Hubungan Seksual Pranikah Remaja Indonesia. Jurnal Kesehatan Masyarakat Nasional 10(1): 44-50.

Pringle, J., Mills, K.L., McAteer, J., Jepson, R., Hogg, E., Anand, N., \& Blakemore, S-J. (2017). The Physiology of Adolescent Sexual Behaviour: A Systematic Review. Cogent Social Sciences 3: 1-14.

Rahyani, K.Y., Utarini, A., Wilopo, S.A., \& Hakimi, M. (2012). Premarital Sexual Inisiation of Adolescence. Jurnal Kesehatan Masyarakat Nasional 7(4): 180-185.

Ratnawati, D. \& Astari, I.D. (2019). Hubungan Tingkat Stress denan Perilaku Berpacaran pada Remaja di SMA X Cawang Jakarta Timur. Jurnal Profesi Medika 13(1), 15-21.

Rosdarni, Djaswadi D., \& Sumarni, D.W. (2015). Pengaruh Faktor Personal terhadap Perilaku Seksual Pranikah pada Remaja. Jurnal Kesehatan Masyarakat Nasional 9(3), 214-221.

Setiawan, R. \& Nurhidayah, S. (2008). Pengaruh Pacaran terhadap Perilaku Seks Pranikah, Jurnal Soul 1(2), 59-72.

Suwarni, L., \& Arfan, I. (2015). Hubungan antara Lovestyle, Sexual Attitudes, Gender Attitude dengan Perilaku Seks Pra-Nikah. Jurnal Vokasi Kesehatan 1(1), 28-38.

Suwarsi. (2016). Analisis Faktor Penyebab Perilaku Seksual Pranikah ada Remaja di Desa Wedomartani Sleman Yogyakarta. Jurnal Ners dan Kebidanan Indonesia 4(1), 
39-43.

Wellings, K., Collumbien, M., Slaymaker, E., Singh, S., Hodges, Z., Patel, D., \& Bajos, N. (2006). Sexual Behaviour in Context: $A$ Global Perspective. Lancet 368, 17061728.

Wulan, T.R. \& Muslihudin. (2003). Perilaku Seksual Remaja di Perdesaan (Studi tentang Perilaku Seks dan Reproduksi Sehat Remaja di Kecamatan Kedungbanteng Kabupaten Banyumas). Jurnal Pembangunan Pedesaan 3(2), 8190.

Yunus, H. S. (2010). Metodologi Penelitian Wilayah Kontemporer. Pustaka Pelajar, Yogyakarta. 